\title{
Toxic Epidermal Necrolysis after Pemetrexed and Cisplatin for Non-Small Cell Lung Cancer in a Patient with Sharp Syndrome
}

\author{
Cornelia Then $^{\mathrm{a}} \quad$ Jobst C. von Einem ${ }^{\mathrm{a}} \quad$ Daniel Müller $^{\mathrm{b}} \quad$ Michael J. Flaig $^{\mathrm{b}}$ \\ Rudolf M. Huber ${ }^{a}$ Martin Reincke ${ }^{a}$

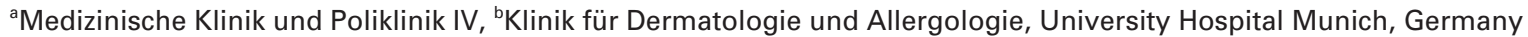

\section{Keywords}

Pemetrexed - Non-small cell lung cancer - Skin toxicity .

Toxic epidermal necrolysis

\section{Summary}

Background: Pemetrexed is an antifolate drug approved for maintenance and second-line therapy, and, in combination with cisplatin, for first-line treatment of advanced nonsquamous non-small cell lung cancer. The side-effect profile includes fatigue, hematological and gastrointestinal toxicity, an increase in hepatic enzymes, sensory neuropathy, and pulmonary and cutaneous toxicity in various degrees. Case Report: We present the case of a 58-year-old woman with history of Sharp's syndrome and adenocarcinoma of the lung, who developed toxic epidermal necrolysis after the first cycle of pemetrexed, including erythema, bullae, extensive skin denudation, subsequent systemic inflammation and severe deterioration in general condition. The generalized skin lesions occurred primarily in the previous radiation field and responded to immunosuppressive treatment with prednisone. Conclusion: Although skin toxicity is a wellknown side effect of pemetrexed, severe skin reactions after pemetrexed administration are rare. Caution should be applied in cases in which pemetrexed is given subsequent to radiation therapy, especially in patients with pre-existing skin diseases.

\section{Introduction}

After intracellular metabolization to a pentaglutamate form, pemetrexed inhibits thymidylate synthase, dihydrofolate reductase and glycinamide ribonucleotide transferase, all

\author{
Schlüsselwörter \\ Pemetrexed - Nicht-kleinzelliges Lungenkarzinom · \\ Toxische epidermale Nekrolyse
}

\section{Zusammenfassung}

Hintergrund: Pemetrexed ist ein Folatantagonist, der für die Erhaltungs- und Zweitlinientherapie und in Kombination mit Cisplatin für die Erstlinientherapie des fortgeschrittenen Adenokarzinoms der Lunge zugelassen ist. Bekannte Nebenwirkungen sind Abgeschlagenheit, hämatologische, gastrointestinale, pulmonale und hepatische Toxizität, sensorische Neuropathie und Hautreaktionen verschiedener Schweregrade. Fallbericht: Wir berichten von einer 58-jährigen Patientin mit vorbekanntem Sharp-Syndrom und einem Adenokarzinom der Lunge, die nach dem ersten Zyklus Pemetrexed in Kombination mit Cisplatin eine toxische epidermale Nekrolyse mit Rötung, Blasenbildung, großflächiger Hautablösung, nachfolgender systemischer Entzündungsreaktion und schwerer Minderung des Allgemeinzustandes erlitt. Die generalisierten Hautläsionen bildeten sich in erster Linie im vormaligen Bestrahlungsfeld und sprachen auf eine immunsuppressive Therapie mit PrednisoIon an. Schlussfolgerung: Obwohl Hauttoxizität zu den bekannten Nebenwirkungen von Pemetrexed gehört, sind schwere Hautschädigungen nach Pemetrexedgabe selten. Besondere Vorsicht ist bei einer Pemetrexedgabe nach Strahlentherapie und bei Patienten mit vorbestehenden Hauterkrankungen geboten.

involved in folate metabolism, thus blocking both the purine and pyrimidine pathways of DNA synthesis [1]. In 2008, a combination of pemetrexed with cisplatin was approved by the European Medicines Agency and the US Food and Drug Administration for first-line treatment of metastatic

\section{KARGER \\ Fax +497614520714 \\ Information@Karger.de}

www.karger.com (c) 2012 S. Karger GmbH, Freiburg

0378-584X/12/3512-0783\$38.00/0

Accessible online at:

www.karger.com/onk
Cornelia Then, M.D

Medizinische Klinik und Poliklinik IV

University Hospital Munich

Ziemssenstraße 1, 80336 Munich, Germany

cornelia.then@med.uni-muenchen.de 
non-small cell lung cancer (NSCLC) with other than squamous cell histology. This combination has been tested in phase III clinical trials, and has shown promising antitumor activity with a generally mild toxicity profile [2-4]. The most common adverse events with a frequency of more than $5 \%$ are hematological (neutropenia grade $3-4$ in $25 \%$ of patients), gastrointestinal and hepatic toxicity, fatigue, sensory neuropathy and skin reactions [2-5]. Cutaneous toxicity has been reported in $10-22 \%$ of patients, usually as a grade $1-2$ rash or periorbital and limb edema, but also in various other forms, such as diffuse hyperpigmentation, urticarial vasculitis and generalized exanthematous pustulosis [3, 5-8]. Nevertheless, to our knowledge, toxic epidermal necrolysis (TEN) related to pemetrexed has been described in only 2 other cases to date $[9,10]$.

\section{Case Report}

A 58-year-old woman was diagnosed with adenocarcinoma of the lung stage IIIb with negative EGFR mutational status in March 2011. The patient was a current smoker. There was no medical history apart from Sharp's syndrome, diagnosed in 2003 and treated with $2 \mathrm{mg}$ prednisone daily and $15 \mathrm{mg}$ methotrexate weekly. Beside an initial Raynaud's phenomenon and occasional palmar and plantar erythema, no other skin lesions were associated with the Sharp's syndrome. The patient received 2 cycles of chemotherapy with cisplatin $\left(20 \mathrm{mg} / \mathrm{m}^{2}\right.$ days $\left.1-4\right)$ and vinorelbine $\left(50 \mathrm{mg} / \mathrm{m}^{2}\right.$ days 1,8 and 15$)$ and simultaneous radiation therapy of the primary tumor of the middle lobe and infracarinal lymph node metastases with an overall dose of $64 \mathrm{~Gy}$. After 2 cycles of chemotherapy and completion of the radiation therapy, a PET-CT scan was performed, which revealed partial local tumor response, but also 2 brain metastases. Due to these findings, the chemotherapy was switched to cisplatin $\left(75 \mathrm{mg} / \mathrm{m}^{2}\right.$ day 1$)$ and pemetrexed $\left(500 \mathrm{mg} / \mathrm{m}^{2}\right.$ day 1$)$, which was administered 26 days after the completion of the radiation therapy. Supplementation with $5 \mathrm{mg}$ folic acid daily orally and $1 \mathrm{mg}$ vitamin B12 monthly subcutaneously was each started 7 days prior to cisplatin/ pemetrexed. After detection of the brain metastases and 15 days before the administration of cisplatin/pemetrexed, the patient received $12 \mathrm{mg}$ dexamethasone daily. No other drugs were started.

Two days after the first cycle of cisplatin and pemetrexed, the patient presented a generalized pruritic rash, primarily involving the radiation sites at the chest wall, but also the arms, legs and face, especially the lips. Within 3 days, the initially small erythematous macules aggravated, forming large bullae containing clear liquid and leading to desquamation with large areas of epidermal detachment and multiple bleeding wounds (fig. 1A and B). As in a previously reported case of TEN after pemetrexed application [9], we detected no sign of mucosal or ocular involvement. Skin biopsy revealed keratinocyte apoptosis, epidermal separation at a sub-epidermal level and overlying extensive epidermal necrosis. A scanty lymphocytic infiltrate was visible in the dermis (fig. 1C). On the day of the onset of the rash, the hemoglobin level was $8.6 \mathrm{~g} / \mathrm{dl}$, the platelet count $226 \times 10^{9} / 1$ and the white blood cell count $4.3 \times 10^{9}$ cells $/ 1$ with $71 \%$ polymorphonuclear leukocytes. Further laboratory tests revealed C-reactive protein $(\mathrm{CRP})$ of $2.1 \mathrm{mg} / \mathrm{dl}(<0.5 \mathrm{mg} / \mathrm{dl})$ and lactate dehydrogenase (LDH) of $193 \mathrm{U} / 1$ (> $250 \mathrm{U} / \mathrm{l})$.

Immunosuppressive treatment with $75 \mathrm{mg}$ prednisone daily intravenously was started on the day that the rash appeared and $180 \mathrm{mg}$ fexofenadine 3 times daily orally was added 3 days later. Topical treatment was performed with a potent steroid cream (betamethasone dipropionate, $0.64 \mathrm{mg} / \mathrm{g}$ ).
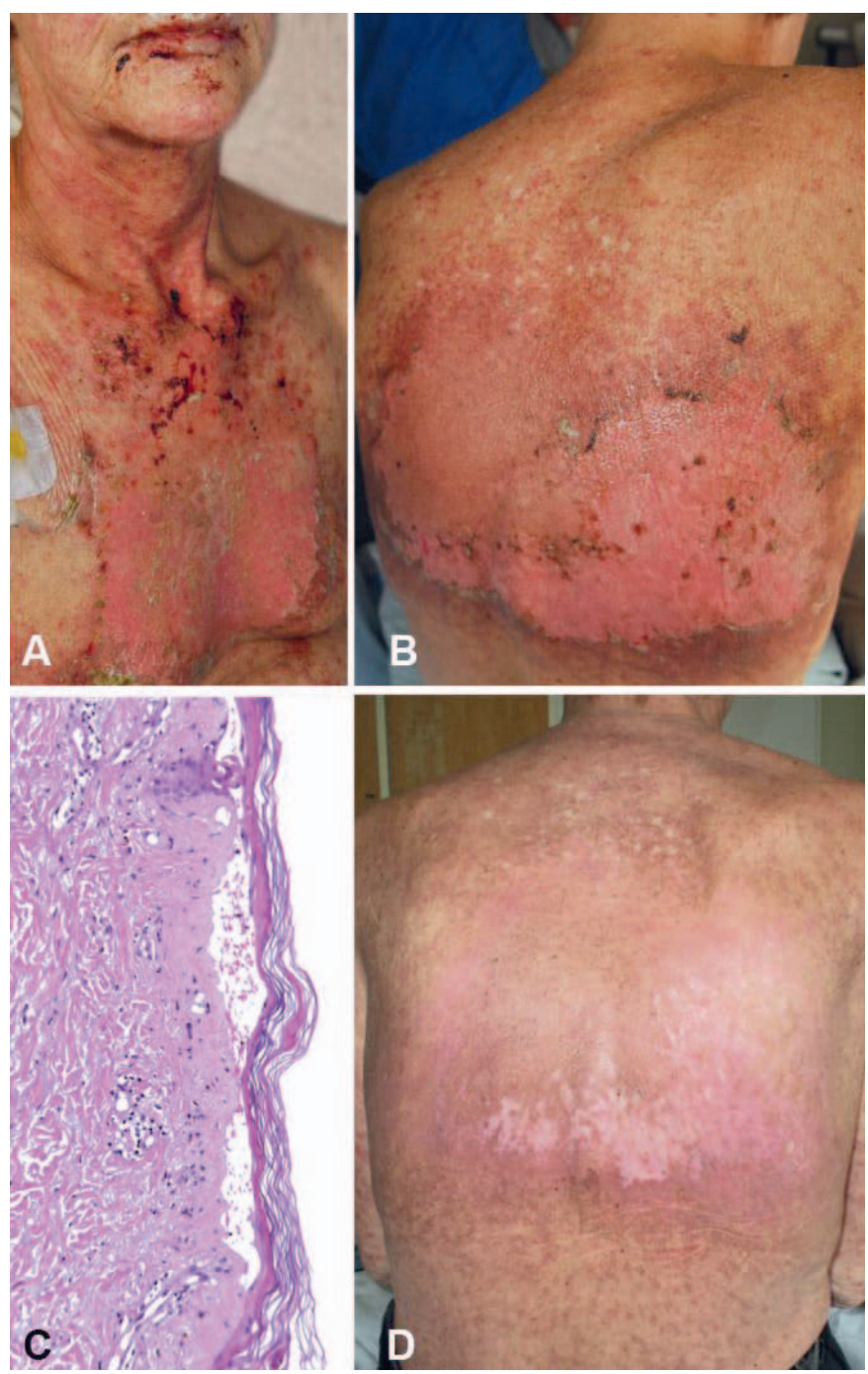

Fig. 1. Chest wall $\mathbf{A}$ and back $\mathbf{B}$ of the patient during the first week after the onset of the rash display large areas of epidermal detachment. C $\mathrm{H}$ and $\mathrm{E}$ staining of the skin biopsy shows epidermal separation at a sub-epidermal level, overlying extensive epidermal necrosis and a scanty lymphocytic infiltrate in the dermis. D Back of the patient 3 weeks after the onset of the rash.

The total white blood cell count dropped to $0.4 \times 10^{9}$ cells/ 2 days after the onset of the rash and granulocyte-colony stimulating factor treatment (30 million units filgrastim daily) was started. Neutropenia lasted for 3 days and the patient required 4 erythrocyte and 2 platelet transfusions to maintain a hemoglobin level above $8.0 \mathrm{~g} / \mathrm{dl}$ and a platelet count above $10 \times 10^{9} / 1$. Antibiotic treatment with piperacillin-tazobactam was started after the laboratory inflammation signs increased, and the prednisone dose was decreased to $50 \mathrm{mg}$ daily 5 days after the onset of the rash. Subsequently, prednisone was tapered over the following weeks and was replaced by the previous medication dexamethasone.

CRP and LDH, which may also be prognostic parameters [11], rose to a maximum of $29 \mathrm{mg} / \mathrm{dl}$ and $265 \mathrm{U} / 16$ days after the rash development. The patient experienced a severe deterioration of general health, including fever and staphylococcal septicemia. The skin lesions were painful and continuous morphine application was necessary. Due to severe involvement of the lips, total parenteral nutrition was necessary for several days. According to the SCORTEN severity-of-illness score [12], predicted mortality was $36 \%$. The first sign of improvement of the skin lesions was 
detectable 7 days after the presentation of the rash. Figure 1D shows the patient's back 3 weeks after the onset of the rash. The total duration of the hospital stay caused by the severe skin reaction was 23 days. Pemetrexed was terminated and the patient received $30 \mathrm{mg} / \mathrm{m}^{2}$ docetaxel weekly with no further severe side effects.

\section{Discussion}

TEN is a severe epidermolytic reaction with an incidence of 1-2 cases per million in the western population [13]. It is associated with drugs, especially allopurinol, antibiotics and anticonvulsants, or less frequently, with bacterial or viral infections, such as mycoplasma pneumonia, herpes simplex and HIV. In rare cases, the etiology remains unknown [13-15].

Aggravating factors in the patient presented here may have been the previous radiotherapy, chemotherapy-induced neutropenia, and the pre-existing Sharp's syndrome. The most severe skin lesions occurred in the previous radiation field. Although the patient had no visible skin irritation in the radiation field prior to the administration of pemetrexed, and the last radiation therapy had been applied 26 days before the onset of the rash, a pre-existing skin irritation may have worsened the problem. Radiation-recall dermatitis after pemetrexed application has been described after a time interval as long as 27 years following radiation therapy [16], with attempted explanations suggesting stem-cell depletion and/or mutations as well as local vascular damage causing a diminished skin recovery potential in the radiotherapy field. Independently of the use of pemetrexed, radiotherapy or the existence of cancer has been shown to have an impact on TEN incidence $[13,17]$. On the other hand, a combination of radiation therapy with pemetrexed up to the dose of $600 \mathrm{mg} / \mathrm{m}^{2}$ has been reported without major skin reaction in a phase I study [18], and early sites of cutaneous involvement are typically the presternal region and the face [13], and may coincidentally match with the radiation field in our patient.

The aggravation of the skin lesions converged with the onset of neutropenia. The 2 previously reported cases of TEN after pemetrexed administration were also both associated with pancytopenia, although not strictly speaking neutropenia $[8,9]$. Pathogenically, TEN is thought to be a specific drug hypersensitivity reaction [13]. Cytotoxic T lymphocytes and a loss of function of $\mathrm{CD} 4^{+} \mathrm{CD} 25^{+}$regulatory $\mathrm{T}$ cells may play a major role in the initiation phase $[13,19]$. Therefore, immunosuppression or immunomodulation caused by different conditions, such as chemotherapy or AIDS (the latter increasing the risk 1,000-fold [15]), could facilitate the development of
TEN by suppressing regulatory T cells. Additionally, neutropenia is a general risk factor for infection, including bacterial infections of affected skin, and it is conceivable that due to an altered cytokine environment it may also restrain the healing process.

Sharp's syndrome is a mixed connective tissue disorder with frequent skin involvement characterized by vascular lesions, such as intimal proliferation and medial hypertrophy, primarily affecting small vessels and becoming manifest in a Raynaud's phenomenon, swollen hands and puffy fingers or scleroderma-like vasculopathy [20]. Even though visible cutaneous manifestations are often restricted to hands and feet, as in the patient described here, Sharp's syndrome is a systemic disease and the underlying vascular alterations may also be present in other skin areas, theoretically promoting cutaneous lesions caused by different agents.

Because of its potential fatality, TEN is a medical emergency. The high morbidity and mortality of TEN is caused not least by its rarity and the underestimation of its severity. Initial small and inconspicuous maculae rapidly develop into TEN and the patient may require intensive care. Therefore, it is crucial to stop the alleged causing agent immediately and to assure the diagnosis. The most serious problem, however, is the lack of an established standard treatment. Due to the rarity of TEN, randomized controlled trials assessing the efficacy of different treatment options do not exist, and many case reports lack important information about response to treatment and time of hospitalization [21]. The use of corticosteroids, high-dose intravenous immunoglobulin and other immunosuppressive therapies remains controversial and has proved no clear benefit compared to supportive treatment alone [13, 22, 23]. Especially if septicemia is present, as often occurs when large skin areas are denuded, immunosuppression may herald the possibility of an exacerbation of the infection. Nevertheless, most authors currently favour the use of corticosteroids or intravenous immunoglobulin [13, 15, 21]. Prednisone was started at the day of the first emergence of the rash in the patient described here, but was not successful in preventing severe skin detachment. However, as in the 2 other cases of TEN after pemetrexed, which were also treated with systemic steroids $[8,9]$, the outcome for the patient was favorable.

\section{Disclosure Statement}

The authors have no conflict of interest/competing interests.

\section{References}

1 Shih C, Chen VJ, Gossett LS, Gates SB, Mackellar WC, Habeck LL, Shackelford KA Mendelsohn LG, Soose DJ, Patel VF, Andis SL, Bewley JR, Rayl EA, Moroson BA, Beardsley GP, Kohler W, Ratnam M, Schultz RM: LY231514, a pyrrolo[2.3-d]pyrimidine-based antifolate that inhibits multiple folate-requiring enzymes. Cancer Res 1997; 57:1116-1123.

2 Scagliotti GV, Parikh P, von Pawel J, Biesma B, Vansteenkiste J, Manegold C, Serwatowski P,
Gatzemeier U, Digumarti R, Zukin M, Lee JS, Mellemgaard A, Park K, Patil S, Rolski J, Goksel T, de Marinis F, Simms L, Sugarman KP, Gandara D. Phase III study comparing cisplatin plus gemcitabine with cisplatin plus pemetrexed in chemo- 
therapy-naive patients with advanced-stage nonsmall-cell lung cancer. J Clin Oncol 2008;26:35433551.

3 Fuld AD, Dragnev KH, Rigas JR. Pemetrexed in advanced non-small-cell lung cancer. Expert Opin Pharmacother 2010;11:1387-1402.

4 Cohen MH, Cortazar P, Justice R, Pazdur R Approval summary: Pemetrexed maintenance therapy of advanced/metastatic nonsquamous, non-small cell lung cancer (NSCLC). Oncologist 2010;15:1352-1358.

5 Belani CP, Brodowicz T, Ciuleanu TE, Krzakowski M, Yang SH, Franke F, Cucevic B, Madhavan J, Santoro A, Ramlau R, Liepa AM, Visseren-Grul C, Peterson P, John WJ, Zielinski CC. Quality of life in patients with advanced non-smallcell lung cancer given maintenance treatment with pemetrexed versus placebo (H3E-MC-JMEN): Results from a randomised, double-blind, phase 3 study. Lancet Oncol 2012;13:292-299.

6 Lopes G, Vincek V, Raez LE: Pemetrexed-associated urticarial vasculitis. Lung Cancer 2006;51: 247-249.

7 Vitiello M, Romanelli P, Kerdel FA: Painful generalized erythematous patches: A severe and unusual cutaneous reaction to pemetrexed. J Am Acad Dermatol 2011;65:243-244.

8 Bracke A, Van Marck E, Lambert J: Acute generalized exanthematous pustulosis after pemetrexed, and recurrence after re-introduction. Clin Exp Dermatol 2009;34:337-339.

9 Bosch-Barrera J, Gaztañaga M, Ceballos J, PérezGracia JL, López-Picazo JM, García-Foncillas J, Ferrer M, Sanz ML, Pretel M, Idoate MA, GilBazo I: Toxic epidermal necrolysis related to pemetrexed and carboplatin with vitamin B12 and folic acid supplementation for advanced non-small cell lung cancer. Onkologie 2009;32:580-584.

10 Tummino C, Barlesi F, Tchouhadjian C, Tasei AM, Gaudy-Marqueste C, Richard MA, Astoul P: Severe cutaneous toxicity after Pemetrexed as second line treatment for a refractory non small cell lung cancer. Rev Mal Respir 2007;24:635-638.

11 Yun SJ, Choi MS, Piao MS, Lee JB, Kim SJ, Won YH, Lee SC: Serum lactate dehydrogenase is a novel marker for the evaluation of disease severity in the early stage of toxic epidermal necrolysis. Dermatology 2008;217:254-259.

12 Bastuji-Garin S, Fouchard N, Bertocchi M, Roujeau JC, Revuz J, Wolkenstein P: SCORTEN: A severity-of-illness score for toxic epidermal necrolysis. J Invest Dermatol 2000;115:149-153.

13 Harr T, French LE: Toxic epidermal necrolysis and Stevens-Johnson syndrome. Orphanet J Rare Dis 2010;5:39.

14 Mockenhaupt M, Viboud C, Dunant A, Naldi L, Halevy S, Bouwes Bavinck JN, Sidoroff A, Schneck J, Roujeau JC, Flahault A: StevensJohnson syndrome and toxic epidermal necrolysis: assessment of medication risks with emphasis on recently marketed drugs. The EuroSCAR-study. J Invest Dermatol 2008;128:35-44.

15 Tan SK, Tay YK: Profile and pattern of StevensJohnson syndrome and toxic epidermal necrolysis in a general hospital in singapore: Treatment outcomes. Acta Derm Venereol 2012;92:62-66.

16 Barlési F, Tummino C, Tasei AM, Astoul P: Unsuccessful rechallenge with pemetrexed after a previous radiation recall dermatitis. Lung Cancer 2006;54:423-425.
17 Aguiar D, Pazo R, Durán I, Terrasa J, Arrivi A, Manzano H, Martín J, Rifá J: Toxic epidermal necrolysis in patients receiving anticonvulsants and cranial irradiation: A risk to consider. J Neurooncol 2004;66:345-350.

18 Seiwert TY, Connell PP, Mauer AM, Hoffman PC, George CM, Szeto L, Salgia R, Posther KE, Nguyen B, Haraf DJ, Vokes EE: A phase I study of pemetrexed, carboplatin, and concurrent radiotherapy in patients with locally advanced or metastatic non-small cell lung or esophageal cancer. Clin Cancer Res 2007;13:515-522.

19 Azukizawa H: Animal models of toxic epiderma necrolysis. J Dermatol 2011;38:255-260.

20 Grader-Beck T, Wigley FM: Raynaud's phenomenon in mixed connective tissue disease. Rheum Dis Clin North Am 2005;31:465-481.

21 Del Pozzo-Magana BR, Lazo-Langner A, Carleton B, Castro-Pastrana LI, Rieder MJ: A systematic review of treatment of drug-induced StevensJohnson syndrome and toxic epidermal necrolysis in children. J Popul Ther Clin Pharmacol 2011; 18:e121-133.

22 Kardaun SH, Jonkman MF: Dexamethasone pulse therapy for Stevens-Johnson syndrome/toxic epidermal necrolysis. Acta Derm Venereol 2007;87:144-148.

23 Schneck J, Fagot JP, Sekula P, Sassolas B, Roujeau JC, Mockenhaupt M: Effects of treatments on the mortality of Stevens-Johnson syndrome and toxic epidermal necrolysis: A retrospective study on patients included in the prospective EuroSCAR Study. J Am Acad Dermatol 2008;58:33-40. 